Gizem Erdoğan

İzmir Demokrasi University, gizemerdogan@gmail.com, İzmir-Turkey

\begin{tabular}{l|l|l}
\hline \hline DOI & http://dx.doi.org/10.12739/NWSA.2019.14.2.E0045 \\
\hline ORCID ID & $0000-0002-1376-6457$ \\
\hline \multicolumn{2}{l}{ CORRESPONDING AUTHOR } & Gizem Erdoğan \\
\hline
\end{tabular}

\title{
IDENTIFIYING URBAN FRINGE SPATIAL CHARACTER WITH FRACTAL ANALYSIS: AKHAN, DENIZLI
}

\begin{abstract}
Urban sprawl and density are spatial reflections is surfaced with increasing demand constrain of urban dynamics. The inception of town growth set off urban fringe-belt development. Fractal analysis method is used to define the formal construct of different patterns. Recent 30 years many studies with the fractal aspects explained relations of urban boundaries and the fractal dimension. Urban fringe transformation is more important for determining of urban boundaries. The study assumes that this urbanization fabric can be explained by fractal geometry. A two-phased method is proposed here in which first is fractal dimension is applied to detect spatial discontinuity of study area via different human settlement area, and second is detection of urban pattern changes. Akhan is $7 \mathrm{~km}$ far from the Denizli city and it is at the side of Denizli Afyon Road. In order to represent the spatial character of the urban fabric of Akhan, which is an urban inner wall, three samples were chosen, and the discontinuity of the urban texture was calculated with a fractal dimension: the first area is at the north of the settlement, second is South at the settlement and the last one in at the center of the settlement. In conclusion, Akhan maintains its compact structure and rural identity has been determined in accordance with fractal analysis. In this respect, the legacy of the spatial characteristics of the new metropolitan cities with increasing responsibility areas and the responsibility of zoning has shown that the model used in this study can be used as a new model to determine the transitions and changes in texture.
\end{abstract}

Keywords: Urban Morphology, Urban Fringe, Fractal Dimension, Akhan, Denizli

\section{INTRODUCTION}

Urban pattern is considered the composition of land coverage of settlement as solid mass (figure) to open voids (ground) by morphologically. Furthermore, urban pattern is including geographical feature and socio-cultural stratification. Morphology could be described with the simplest definition is "cognition of shape", more clearly, analysis of physical structures at different scales as well as patterns of movement, land use, occupation in process colligation elements of designating urban pattern. Urban morphology can be defined basically focusing on the physical forms of urban areas [1 and 2], detail analyzing human settlements' forms with its elements [3, 4, 5, 6 and 7], historical development processes $[8,9,10,11,12,13$ and 14] and concept of urban fringe belt is a theoretical framework to explain urban physical form $[1,15,16,17,18,19,20,21,22,23$ and 24]. Urban sprawl has become a major contemporary problem for both scientists and decision makers for 21 th century cause of constraint on

How to Cite:

Erdoğan, G., (2018). Identifiying Urban Fringe Spatial Character with Fractal Analysis:

Akhan, Denizli, Qualitative Studies (NWSAQS), 14(2):11-17,

DOI: $10.12739 /$ NWSA.2019.14.2.E0045. 
natural resource. In this regard, "correct calculation of urban macroform" represents an important challenge. Urban fringe-belt is one of those approaches is urban morphology. Urban fringe belt is an important morphological concept of its potential as citywide planning during development processes which researched by urban planners and geographers in several decades $[1,18,23,24,25,26,27,28,29,30$ and 31]. Urban fringe belts are the outgrowth spontaneously of the central business district and usually the areas of important as a buffer zone of heritage and ecological corridor, characterized by similar physical, occupational pattern, but different usage [27]. Fringe belt is a morphological concept be referred to the edge of the built-up areas which is the physical result of different morphological periods with combination of large numbers of separate decisions about individual sites $[1,15,17,18,20,21,26$ and 27] with similar vein, using fringe belt processes is a helpful tool integrate into urban planning $[21,24,31,33$ and 34]. The rapid pace of urbanization, urban governance and planning, the structure of urbanization, land use's speculation, non-existent land use planning, inadequate infrastructure, Socio-economic development, transportation models are affected fringe areas [21 and 27]. Urban fringe areas generally fall outside the urban governing boundaries [27]. Conzen, (1969), describes three fringe belts in urban form: an inner, a middle and outer fringe belts at the present edge of the town. Measurement urban fractal dimension of boundaries have not related directly with urban fridgebelt phenomena [3, 35, 36, 37 and 38]. In other respects, urban researchers have been studying urban fringe belt concept since the last half of the century with different perspectives such as spatial, social, economic $[15,18,24,26,27,31$ and 39]. Despite of these studies a few of researches on urban fringe belt context has been undertaken in Turkey [40] none of them relevant fractal dimension.

\section{RESEARCH SIGNIFICANCE}

This paper describes the development and characteristics one of the fringe areas' locations in the urban fabric in Denizli, Akhan. Importance of effects on city's development and potentials are reviewed with the previous studies and determinations and comparisons different residential pattern of Akhan urban fabric. In this process, physical reflections of the formation and change of urbanized area. In the first section; the purpose and describing urban fringe area. the second section; content and the method of the study were defined the inner fringe belt and fractal dimension. Last section, a general assessment and command were made for the results of the research.

\section{METHOD-PROCESS}

Denizli is in southwestern Turkey, in the country's Aegean Region has a population of about 1.018 .735 (2018), attracts many visitors with ancient ruined city of Hierapolis, the city of Laodicea on the Lycus, the ancient metropolis of Phrygia and the nearby thermal hillside of Pamukkale (Figure 1). 


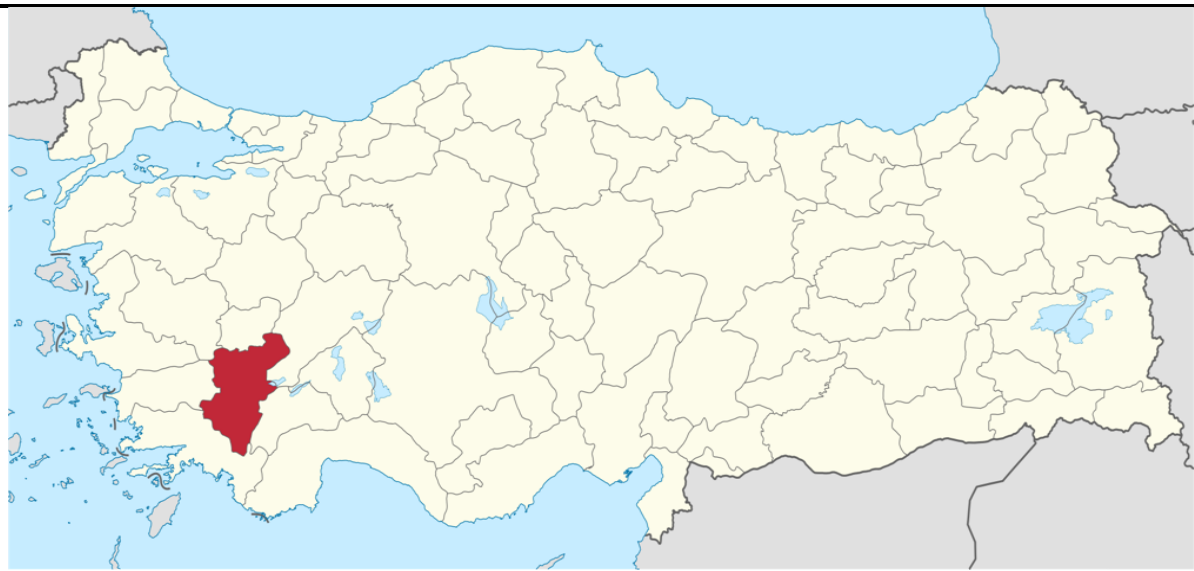

Figure 1. Denizli Turkey (Resource : GoogleMap)

Akhan is $7 \mathrm{~km}$ far from the Denizli city and it is at the side of Denizli Afyon Road has a population about 5691 (2013) (Figure 2). Towns' name came from the last caravansary was built in 1253 years at the west of the Anatolia, by the governor of the Denizli; Şeyfettin Karasungur ibn Abdullah, Emir of Ladik (Figure 3) [41]. Akhan was a village before the new metropolitan municipal law $(6360$ Büyükşehir Belediye Yasası) in 2012, is converted a neighborhood of Denizli is in southwestern industrial city. Although Akhan is a rural-type settlement located outside the city in recent years, the settlement has been the boundary of the city because of urbanization pressure and decentralization policies. As a result of the increasing population of the settlement in line with the new functions (Table 1) and the pressure of the endless urbanization of Denizli, the new construction areas were formed in Akhan, while the city continued its development in the direction of Ankara. This situation made Akhan an urban inner wall belt. The mentioned settlement process caused Akhan to be chosen as the subject of the study.

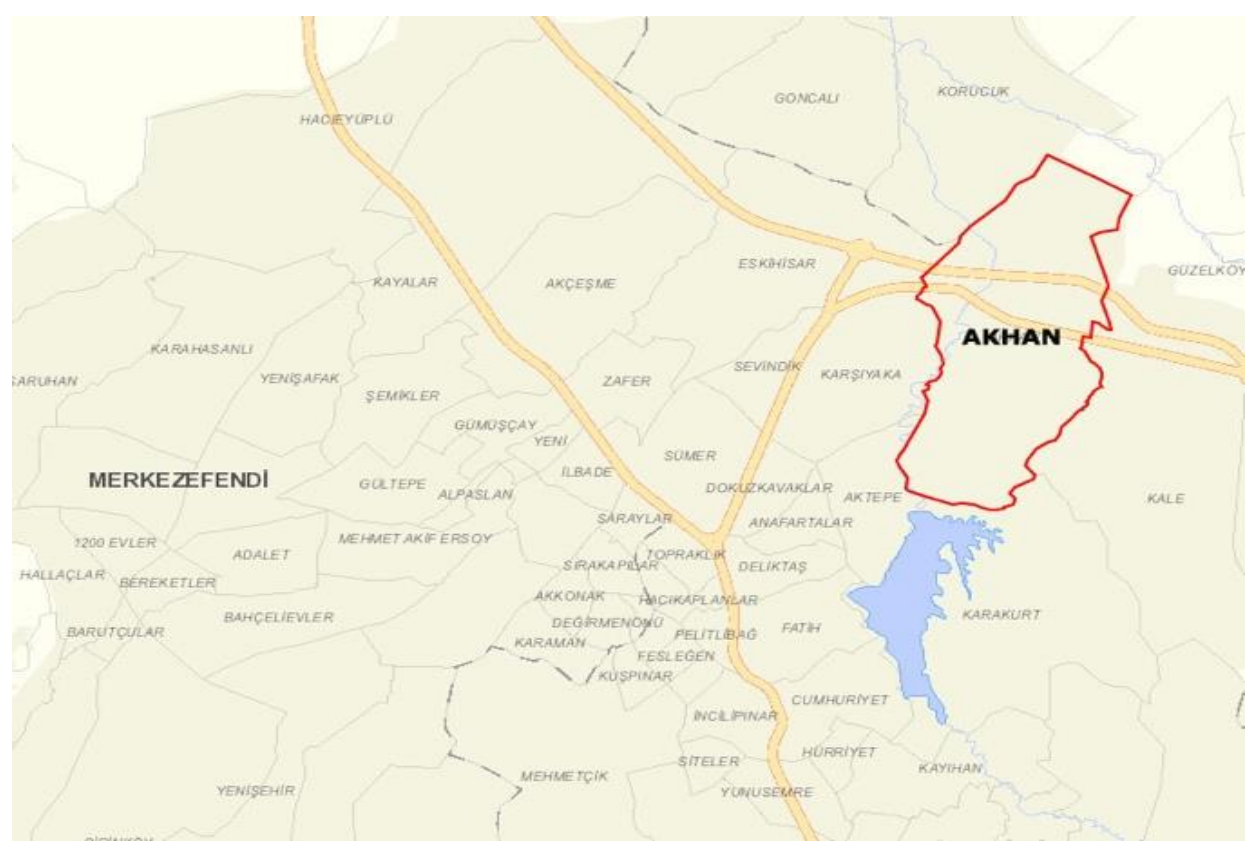

Figure 2. Akhan distict in Denizli (Resource: Google Map) 


\begin{tabular}{|c|c|}
\hline Years & Population \\
\hline 1965 & 484 \\
\hline 1975 & 534 \\
\hline 1985 & 881 \\
\hline 1990 & 1352 \\
\hline 2015 & 5751 \\
\hline 2017 & 5855 \\
\hline
\end{tabular}

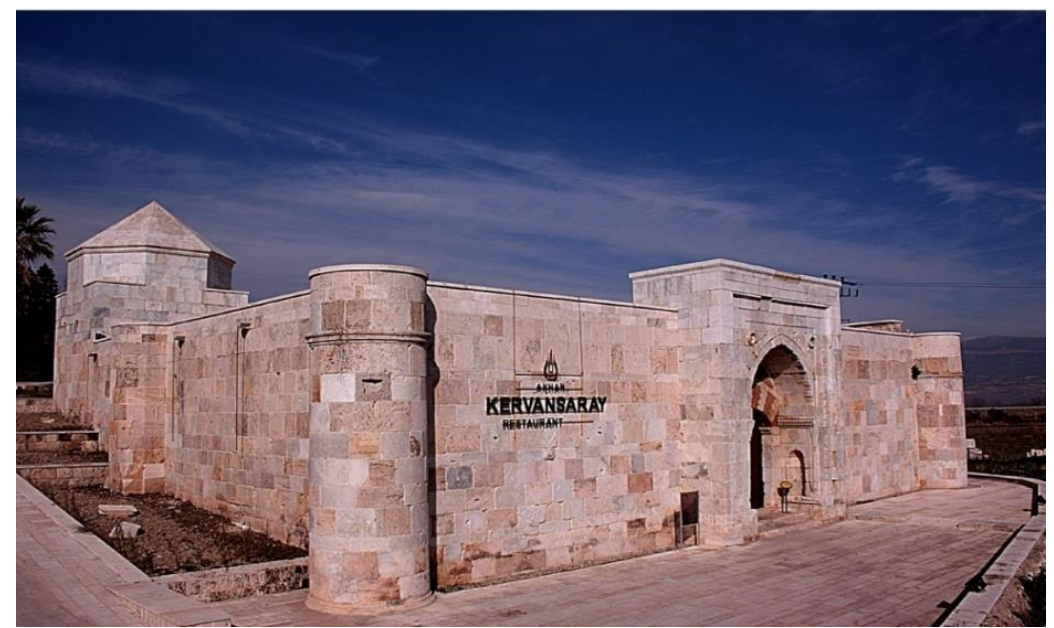

Figure 3. Akhan Caravansary

This study aims to identify dimensions of effecting transforming the spatial characteristic of urban fabric under two steps. First; it was selected three different part of urban fabric of Akhan. The first of them was located northernmost, the second of them was in the south east neighborhood of industrial area. Second Fractalize has been used to measure the fractal dimension of space filling's urban fringe fabric. The box counting method is comparable method to the perimeter measuring method which is used for the coastlines and urban morphology. The basic procedure of box counting method is to systematically is covering the image with a grid, and then count how many boxes of the grid are covering part of the image. Then doing the same thing using smaller boxes. Using the box counting method, fractal dimension is again the slope of the line when is plotted the value of $\log (\mathrm{N})$ on the Y-axis against the value of log(r) on the X-axis (Equation 1). Estimation of fractal dimension D is the slope of the line, $\log (\mathrm{n}(\mathrm{s}))$ and $\log (1 / \mathrm{s})$ (Shen, 2002). $\mathrm{D}=\log (\mathrm{N}) / \log (\mathrm{r})$

Fractal dimensions range between 1 and 2 which corresponds to the range between a line that is straight [42]. A steeper slope means that the dimension is near 2 is more "fractally", that is, it gains in complexity as the box size decreases means urban morphology is compact. A flatter, lower-valued slope, is near 1, means that the object is closer to a straight-line, less "fractally," means urban morphology is sprawl. In this study urban settlement is extracted in line according to the digital satellite maps of different pattern of Akhan and urban boundaries of Ahkan human settlement areas with the aid of Fractalize and GIS (Figure 4, Figure 5, Table 1). Thereby, two type (ward and structuring patterns) of tree different urban pattern each map is available for calculating the fractal dimension (Table 2). 


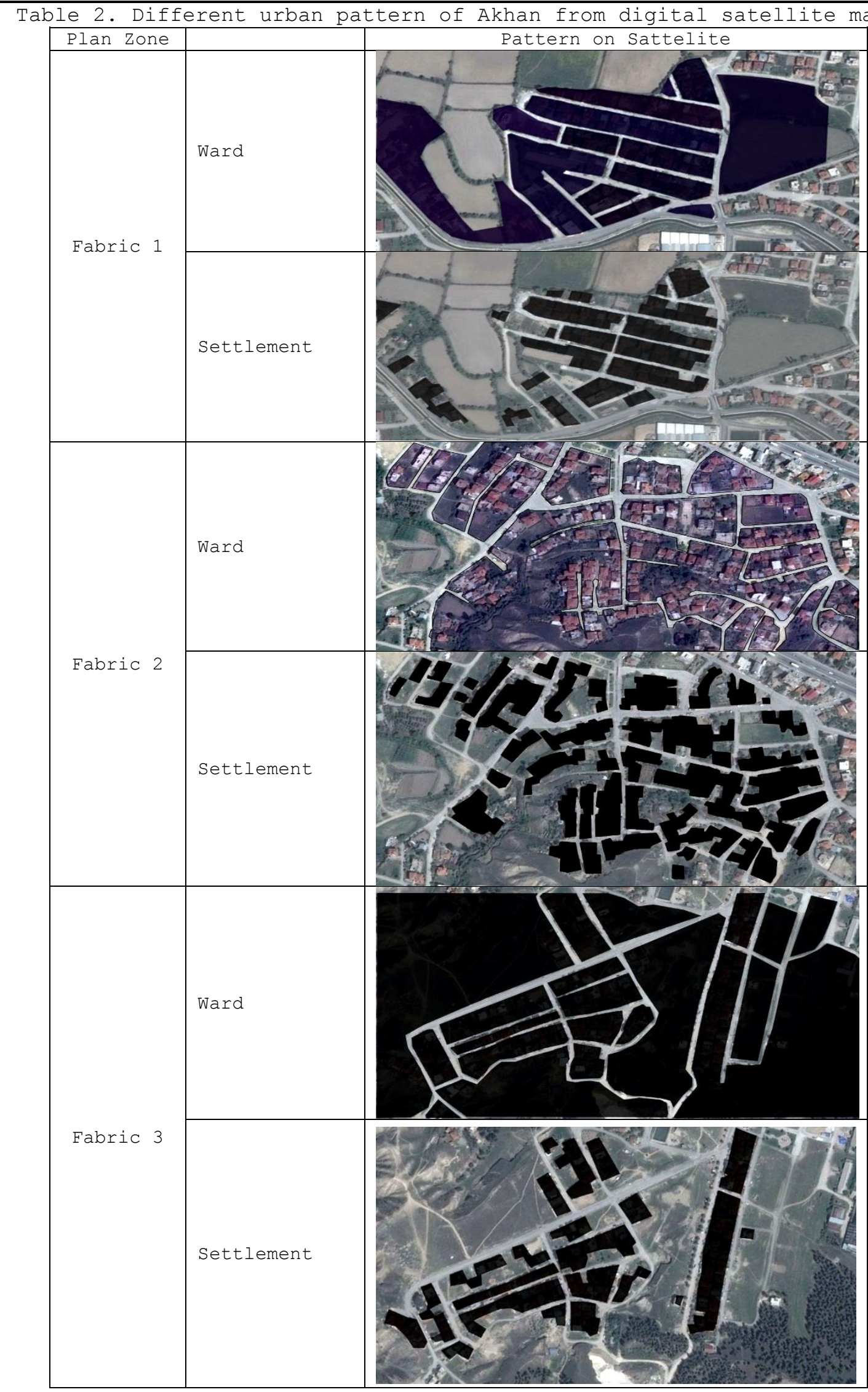


Box-counting algorithm is a methodology in quantifying the measurement of urban spatial structure. Firstly, we transformed the vector layers of different urban settlement spots into raster images, then fractal dimensions of maps are calculated with the help of Fractalize. The urban settlement maps represent different process of evolution of urban spatial pattern on the case of Akhan in different side of settlement.

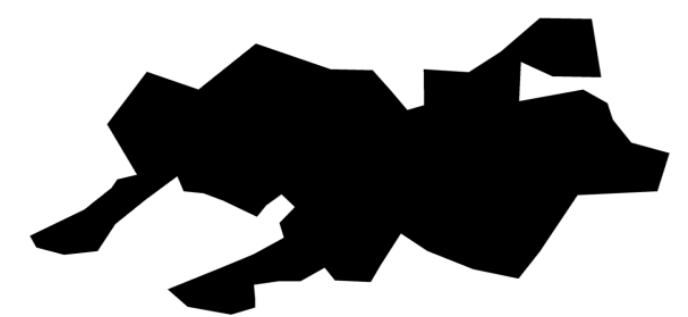

Fractal dimension (D) :1.835 (Box-counting)

Figure 5. Akhan urban settlement pattern

\section{FINDINGS AND DISCUSSIONS}

According to analyse results, even though the fractal dimension of Akhans' ward change between 1.803 and 1.877 and the fractal dimension of the same wards' structuring patterns (building area /human settlement) change between 1.665 and 1.708 (Table 3). Keep compact pattern by the reason of the fractal dimention is over 1.60 [43] both layers warns and building patterns. Here we discuss the changes of fractal dimensions over these three different side of Akhan to explore the spatial morphology is not change remarkably. On the other hand, fabric 3's building area is the lowest value of fractal dimention with 1.665 and conversely is the the maximum value of ward with 1.877. It has been concluded, parcel of land is newest and bigger than the other part of Akhan cause of industrial zone effect.

There were few local authority interventions directly affectingon the land use of Akhan. Agricultural area around the settlement are active. The main change of urban pattern of Akhan was the rehabilitation of the main road between Ankara-Denizli and construction of a industrial areas at the edge of settlement. The reason of Ankara-Denizli transportation road and residential land demands after the new metropolitan municipal law (6360), it was anticipated that Akhan will be redevelopement to residential and commercial land-use units is currently urban growth fallow (Figure 4). 


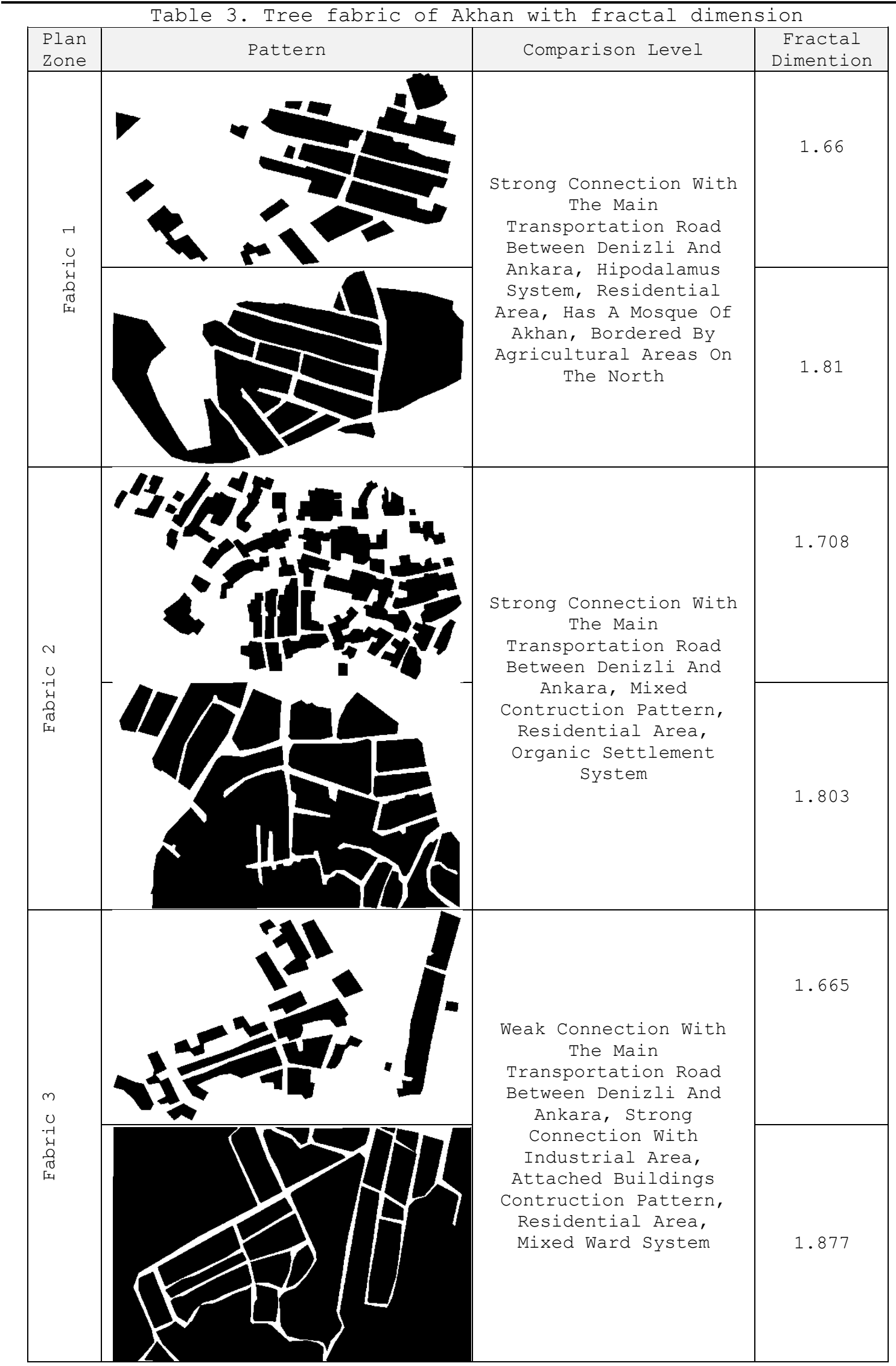




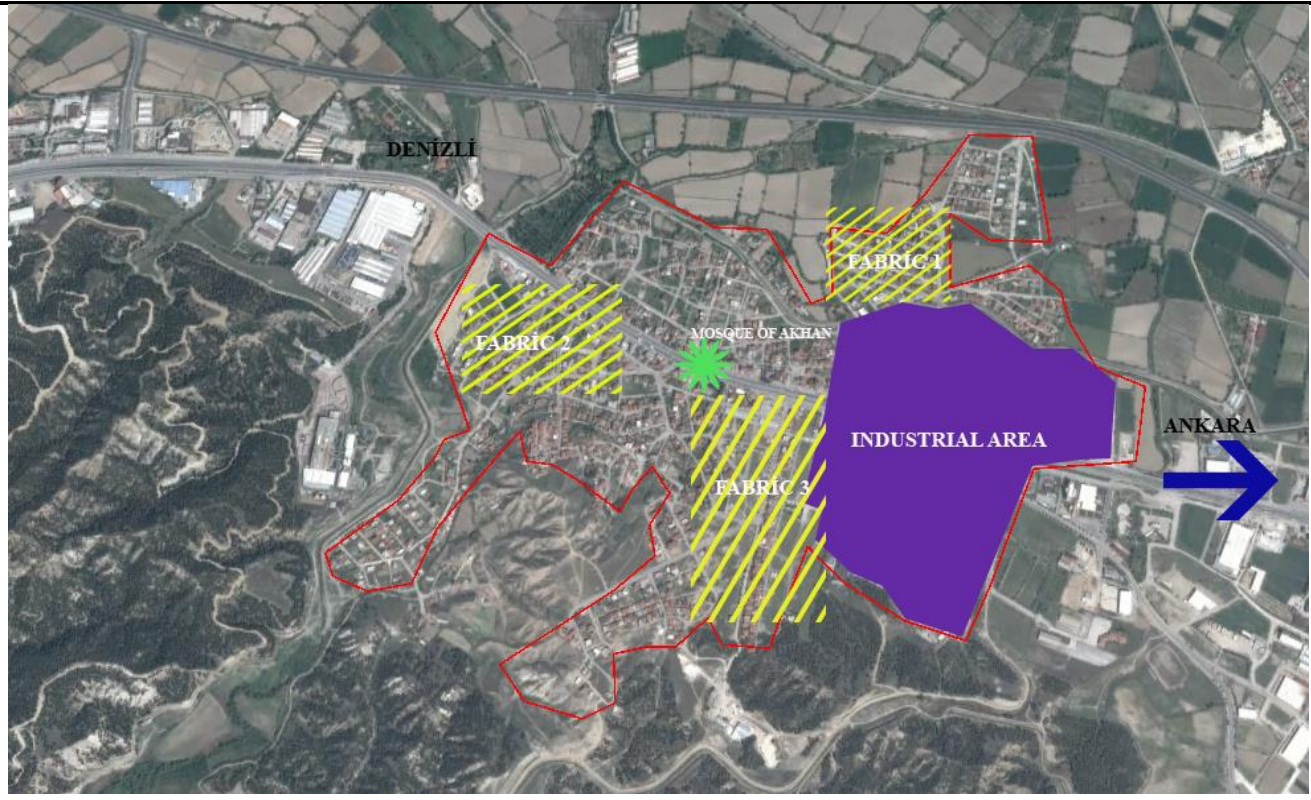

Figure 4. Akhan urban settlement boundary

\section{CONCLUSION}

Urban planners are faced with unprecedented urban population increase with spatial effect on urban growth in recent years. Vieved in relation to the background to firinge belt and fractal research, three main findings from the studys inner fringe belt is nortworthy. First; Akhan, keep compact pattern by the reason of the fractal dimention regardless of the fact new govern status, Secondly; rural identity is still keeping on the edge of the settlement, agricultural area are important and strong treshold for citizen, Thirtly; fractal dimension comparable boundary, image scale were set the same for different side of city. Clearly, can certainly be used a new tool to explain urban fringe belt, urban growth and urban form. Previous studies have recognized to explaining urban growth and urban boundaries [37, 38 and 44]. In Akhan, development plans did not find solution structural components of urban growth and urban fringe belt weaknesses. After the new municipality law, transformation of land use govern issues from the village to the district has a very general land-use terms they are visible on maps of development plans. There is no doubt that the history of Akhan has been different from Turkish urban morphology. Private property and weak urban planning mechanisms give shape to the land. City walls never surrounded Denizli as a young city. Only fixation line in the city is shaped natural thresholds such as agricultural lands and mountain. The description morphogenetic seems Akhan, keep compact pattern by the reason of the fractal dimention. Understanding of the urban growth dynamics constitutes the basis for the effective urban planning. The fractal approach presented in this study is important to realize that town plan develop, and the issues of urban fringe belts need to be given more consideration in urban planning. Optimum utilization of fringe areas in the city is important. This research helps for following study to obtain more realistic models and new methods for the upcoming model new regards fractal dimension and urban fringe belt, through detailed with data sets. So, the title of this paper not only develops a point of view of urban morphology with fractal dimension but also influenced current research. 


\section{REFERENCES}

[1] Whitehand, J.W.R., (1967). Fringe Belts: A Neglected Aspect of Urban Geography. Transactions of the Institute of British Geographers, No:41 (Jun., 1967), 223-233.

[2] Whitehand, J.W.R., (2001). British Urban Morphology: The Conzenian Tradition. Urban Morphology, No:5 (2, 2001), 103-109.

[3] Batty, M. and Longley, P.A., (1987). Urban Shapes as Fractals. Area, 215-221.

[4] Seto, K.C. and Fragkias, M., (2005). Quantifying Spatiotemporal Patterns of Urban Land-Use Change in Four Cities of China with Time Series Landscape Metrics. Landscape ecology, 20(7):871-888.

[5] Chen Y., (2011). Derivation of the Functional Relation Between Fractal Dimension of and Shape Indices of Urban Form, Computers, Environment and Urban Systems, No:35, 442-451.

[6] Chen, Y., (2013). Fractal Analytical Approach of Urban Form Based on Spatial Correlation Function, Chaos, Solitions and Fractals, 49, 47-60.

[7] Thomas I., Frankhauser P., and Biernacki C., (2008). The Morphology of Built-up Landscapes in Wallonia (Belgium): A Classification Using Fractal Indices, Science Direct, Landscape and Urban Planning, 84, 99-115.

[8] Frankhauser, P., (1998). The Fractal Approaches. A New Tool for the Spatial Analysis of Urban Agglomerations. Population: An English Selection, 205-240.

[9] Erdoğan G., (2015). Kent Makroformlarının Mekanı Kullanma Verimliliklerinin Fraktal Boyut ile İncelenmesi, Examining Spatial Efficiency of Cities Using Fractal Dimension. (Doctoral Thesis), Dokuz Eylül University, Graduate School of Natural and Applied Sciences, İzmir, Turkey.

[10] Erdoğan, G. and Çubukçu K.M., (2012). Explaining SpaceEfficiency in Populated Cities Using Urban Explanatory Variables, AESOP Thematic Group on Complexity and Planning 10 th meeting, November 16-17, 2012, Gröningen-Holland.

[11] Erdoğan, G. and Çubukçu K.M., (2014). Explaining Fractal Dimension in Populous Cities, EURAU 2014, Composite Cities, November 12-14,2014, Istanbul-Turkey, 016:001-016:011.

[12] Mcadams, M.A., (2007). Fractal Analyses and The Urban Morphology of a City in a Developing Country: A Case Study of İstanbul, Marmara Coğrafya Dergisi, 15, 150-171.

[13] Sun, Z., Jia, P., Kato, H., and Hayashi, Y., (2007). Distributive Continuous Fractal Analysis for Urban Transportation Network, Proceeding of the Eastern Asia society for Transportation Studies, Vol:6.

[14] Shen, G., (2002). Fractal Dimension and Fractal Growth of Urbanized Areas, International Journal of Geographical Information Science, $16(5): 419-437$.

[15] Barke, M., (1974). The Changing Urban Fringe of Falkirk, Scottish Geographical Magazine 2, 85-97.

[16] Barke, M., (1976). Land Use Succession: A Factor in Fringe-Belt Modification, Area 8, 303-6.

[17] Barke, M., (1982). Beyond the Urban Growth Map: Suggestions for More Analytical Work in Urban Morphology, Teaching Geography 7, $111-15$.

[18] Conzen, M.R.G., (1962). The Plan Analysis of an English City Centre in Norborg, K., (ed.) Proceedings of the International Geographical Union Symposium in Urban Geography, Lund 1960 (Gleerup, Lund) 383-414. 
[19] Conzen Michael, P., Kai, G., and Whitehand, J.W.R., (2012). Comparing Traditional Urban Form in China and Europe: A FringeBelt Approach. Urban Geography 33:1(2012), 22-45.

[20] Dollen, B., (1990). An Historic Geographical Perspective on Urban Fringe-Belt Phenomena, in Slater, T.R. (ed.). The Built Form of Western Cities (Leicester University Press, Leicester) $319-45$.

[21] Gu, K., (2010). Exploring the Fringe-Belt Concept in Auckland: An Urban Morphological Idea and Planning Practice, New Zealand Geographer 66, 44-60.

[22] Ducom, E., (2003). Fringe Belts and Planning: A French Example, Urban Morphology 7, 103-4.

[23] Ducom, E., (2005). Fringe Belts in French Cities: A Comparative Study of Rennes, Nantes and Tours, in Barke, M. (ed.) Approaches in Urban Morphology (Division of Geography, University of Northumbria, Newcastle upon Tyne), 34-43.

[24] Kropf, K., (2009). Aspects of Urban Form. Urban Morphology 13.2 (2009): 105 .

[25] Barke, M., (1990). Morphogenesis, Fringe Belts and Urban Size: An Exploratory Essay, in Slater, T.R. (ed.) The Built Form of Western cities (Leicester University Press, Leicester) 279-99.

[26] Conzen, M.P., (2009). How Cities Internalize Their Former Urban Fringes: A Cross-Cultural Comparison, Urban Morphology 13, $29-$ 51 .

[27] Clark, A.L., (2009). Environmental Challenges to Urban Planning: Fringe areas, Ecological Footprints and Climate Change, Key Challenges in The Process of Urbanization in Ho Chi Minh City: Governance, Socio-economic, and Environmental Issues Workshop Final Paper,16-18 September 2009, Ho Chi Minh City, Vietnam.

[28] Rodrigo Cervantes, N.E., (1999). The Concept of the Fringe Belt in a Mexican City: Morelia, in Transformations of Urban Form, eds R Corona, G L Maffei (Alinea, Firenze), FK2.16 - FK2.20.

[29] Vilagrasa, J., (1990). The Fringe-Belt Concept in a spanish Context: The Case of Lleida', in Slater, T.R.

(ed.) The Built Form of Western cities, Leicester University Press, Leicester.

[30] Whitehand, J.W.R., (1988). Urban Fringe Belts: Development of an Idea, Planning Perspectives 3, 47-58.

[31] Whitehand, J.W.R. and Morton N.J., (2003). Fringe Belts and The Recycling of Urban Land: An Academic Concept and Planning Practice, Environment and Planning B: Planning and Design 2003, vol. 30,819-839.

[32] Kukina, I.V., (2006). Fringe Belts and The Planning of Russian Cities', Urban Morphology 10, 145-6.

[33] Whitehand, J.W., (2007). Conzenian Urban Morphology and Urban Landscapes. In Proceedings of the 6th International space Syntax Symposium, (2007, June).

[34] Whitehand, J.W.R., Gu, K., and Whitehand, S.M., (2011). Fringe Belts and Socioeconomic Change in China". Environment and Planning B: Planning and Design, 38(1), 41-60.

[35] Besussi, E., Chin, N., Batty, M., and Longley, P., (2010). The Structure and Form of Urban Settlements. In Remote Sensing of Urban and Suburban Areas (pp. 13-31). Springer Netherlands.

[36] Longley, P. and Batty. M., (1989). On the Fractal Measurement of Geographical Boundaries, Geographical Analysis, 21(1), 47-67.

[37] Tannier C., Thomas I., Vuidel G., and Pierre Frankhauser, P., (2011). A Fractal Approach to Identifying Urban Boundaries, Geographical Analysis, 04/2011, $43(2): 211-227$. 
[38] Tannier, C. and Thomas, I., (2013). Defining and Characterizing Urban Boundaries: A Fractal Analysis of Theoretical Cities and Belgian Cities. Computers, Environment and Urban Systems, 41 , 234-248.

[39] Carter, H. and Wheatley, S., (1979). Fixation Lines and Fringe Belts Land Uses and Social Areas: Nineteenth-Century Change in The Small Town, Transactions of the Institute of British Geographers New Series 4, 214-38.

[40] Ünlü, T., (2013). Thinking About Urban Fringe Belts: A Mediterranean Perspective. Urban Morphol, 17(1), 5-20.

[41] Yakar, M., Alyılmaz, C., Telci, A, Baygül, E., Çolak, S., Aydın, M., Alyılmaz, S., and Yllmaz, H.M., (2009). 3D laser scanning and photogrammetric measurement of Akhan Caravansary, Scientific Research and Essays, 4(13), 1565-1568.

[42] Mandelbrot, B.B., (1977). Fractals: Form, Chance and Dimension. San Francisco, USA: W.H. Freeman.

[43] Benguigui, L. and Daoud, M., (1991). Is the suburban Railway System a Fractal? Geographical Analysis, 23, 362-368.

[44] Batty, M. and Longley, P.A., (1987). Urban Shapes as Fractals. Area, 215-221. 